\title{
KL River of Life and its Heritage Value
}

\author{
Ahmad Ridzwan Othman, Nur Hasinah Abdul Majid \\ Faculty of Architecture, Planning and Surveying, \\ Universiti Teknologi MARA, 40000 Shah Alam, Malaysia \\ dwan_arc7@yahoo.com
}

\begin{abstract}
Some urban rivers have their respective heritage value and need to be preserved. However, enforcement of river pollution had not given much effect to improvement due to human attitude and behaviour. The purpose of this research is to present an analysis to revitalize the urban river at Precinct 7, River of Life Project, Kuala Lumpur. Through analysis of the precedent studies, the rationale will then be compared to suits the most suitable and relevant proposal. The study revealed that the historic buildings along the river and the river itself should be maintained and integrated to preserve heritage value.
\end{abstract}

Keywords: Urban River; Heritage Value; Sustainable Development; River of Life

eISSN 2398-4295 ( ) 2018. The Authors. Published for AMER ABRA cE-Bs by e-International Publishing House, Ltd., UK. This is an open-access article under the CC BY-NC-ND license (http://creativecommons.org/licenses/by$n c-n d / 4.0 /)$. Peer-review under responsibility of AMER (Association of Malaysian Environment-Behaviour Researchers), ABRA (Association of Behavioural Researchers on Asians) and cE-Bs (Centre for EnvironmentBehaviour Studies), Faculty of Architecture, Planning \& Surveying, Universiti Teknologi MARA, Malaysia.

DOI: http://dx.doi.org/10.21834/ajbes.v3i13.148 


\subsection{Introduction}

In the olden days, rivers are significant in the earliest human settlements. According to Widodo (2012), it is proven by history that civilization rooted from areas at the river bank. The river was a catalyst. It was life to many people.

However, as time goes by, these importance historical cycles being forgotten especially for rivers located in urban areas. With the rapid development of the economy and the acceleration of urbanization, the river pollution occurred continuously, which result in damage to the river ecosystem. Vast quantities of domestic and industrial wastewater flowed into the river, leading to several pollution of the water system. The problems of urban river pollution and ecological damage are becoming more and more critical.

The Ministry of Natural Resources and Environment particularly Department of Irrigation and Drainage was concerned with rivers in Kuala Lumpur and has done many programs over the years to improve our river water quality. In achieving sustainable development, a lot of effort towards water reintegration is taking place not only in Malaysia but all over the world. According to Carmona (2000), it has become the consideration of many cities to use the urban design tool to achieve a sustainable development of cities that has a water body, to create a better public realm at the waterfront area. However, enforcement of river pollution had not given much effect to improvement due to human attitude and behavior. A river is no more a frontage for development but preferably at a backyard where views of the river should be hidden as much as possible. A river is no more a catalyst, and their histories are slowly being forgotten.

\section{Aim and Objectives of Research}

The purpose of this research is to present an analysis to revitalize the urban river at Precinct 7, River of Life (ROL) Project, Kuala Lumpur. Through analysis of the precedent studies, the rationale will then be compared to suits the most suitable and relevant proposal.

The objectives are:

- To analyse how the urban river can be designed towards future development while maintaining the preservation of its heritage value.

- To identify the heritage value along the river of

Precinct 7, KL and study its potentials to ensure the sustaining of its heritage value.

\section{Significant of the Study}

The outcome of the study will encourage the public to be more sensitive towards the heritage value of the urban rivers and address the importance of the river towards the community and the city. This study will also help architects, planners, and decision-makers in finding ways to design a suitable urban river for the public and planning a better river environment. It is also to improve the existing urban river for future development without omitting the heritage aspect. 


\subsection{Literature Review}

A river is a natural watercourse. Usually, freshwater, begins at a source or more often another source and flowing towards another river, a lake or a sea. Urban River is a natural waterway or river that flows through a densely populated area, a location characterized by high human population density a vast human-built features contrast to the area surrounding it (Lynch, 1960). In a simpler meaning, the urban river is a river that runs through a city, town or conurbations. A river, inheritance, has the heritage value in the urban context regarding religious, economic, social, cultural and physical concepts which should be preserved and conserved so that it can be appreciated by the public (Widodo, 2012). Value is the intrinsic reason for heritage conservation and protection. As described by De La Torre \& Mason (2002), no society makes an effort to conserve what it does not value; thus, conservation and protection are the consequence of the heritage value.

Heritage is a property that is inherited. UNESCO (2007) interpreted that heritage is "our bequest or tradition from the previous generation, what we live with today and what we engaged on to the future". Figure 1 shows the meaning of heritage defined in a simpler graphic.

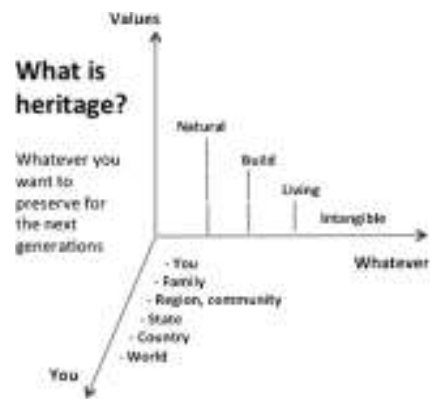

Figure 1: What is Heritage?

Source: LeBlanc (1993)

Researchers have various findings for the potentials of urban rivers in the city of heritage value, a river in urban design, diversity usage of the river, and activities continuation along the river. Abdul Majid (2014), in her Final Design Thesis, has made a comparative study of two rivers which have valuable heritage stories to understand the potentials that they have. Taking into account on how the selected rivers were preserved while at the same time enhancing their heritage value of a river, the precedent studies conclude that different rivers in the various countries have different ways of preserving its heritage value. The primary element to preserve while enhancing their heritage value at the same time is by diversity usage of the river and activities along the river.

Different rivers have different usage depending on where the location is and the surrounding land use. Table 1 shows the summary of diversity usage of the river from the precedent studies. 
Table 1: Comparative Study of Malacca River and Cheonggyecheon River

Usage of the River

Help in Heritage Promotion

Daily Chores

- Drinking

- $\quad$ Cleaning

- $\quad$ Bathing

- Cooking

Water Transportation

Recreational Activity

River Ecology Maintenance

Controlling Flood

Sewerage Disposal
Malacca River,

Malaysia

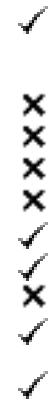

Cheonggyecheon

River, Korea

The two urban rivers have their respective heritage value that should be preserved and both rivers help in the heritage promotion. Regarding using the river as their daily chores, only Cheonggyecheon River used it for cleaning and bathing. Malacca River has the potential to be used for water transportation because of its suitable proportion for boat riding compared to Cheonggyecheon, which is smaller and not suitable for water transportation. Both rivers do provide recreational activities along the rivers, but only Cheonggyecheon River maintains its river ecology. Both rivers also function as controllers so that the urban areas do not flood.

\subsection{Methodology}

The author adopted an existing data collection method from Widodo (2012) who examined the links between the urban river and learning from history at Sumida River, Japan. The method was chosen because of the similar nature of research where both researchers studied the urban river and its history in the context of the urban setting.

Overall site plan of ROL Project was obtained from ROL website to identify the location of the Precinct 7. Case studies by the method of observation at the site were done to explore the urban river and its heritage value, and their potential for future development. Photograph images were taken, and significant features were written down to identify the usage of the urban river and activities that happen along and nearby the River. Evaluations were done to determine the positive and negative values of the river.

Data collected from (1) literature reviews and precedent studies and (2) site observation and analysis were analysed in the scope of the urban river and its heritage value, diversity of usage and activities along the River. A comparative study was made, results and recommendations were tabulated, and later analysed, for future development at Precinct 7 , ROL. 


\subsection{Results and Discussion}

\subsection{Precinct 7, River of Life Project}

Fast development in Kuala Lumpur had taken place over the years especially during the post independent era. These developments grew rapidly and were uncontrolled to the extent of forgoing or scarifying the natural heritage, specifically speaking the river that was once the lifeline of the city in the olden days. Kuala Lumpur has reached a point where dramatic intervention is required to reconnect the community and river. The Ministry of Natural Resources and Environment, particularly the Department of Irrigation and Drainage was concerned with rivers in Kuala Lumpur and had done many programs over the years to improve our river water quality.

In early 2012, the ministry had produced and imposed a draft of the ROL Project for the cleaning, beautification, and development of the Kuala Lumpur's river. The ROL Project, which proposed to orientate the city back to its roots along the Klang and Gombak Rivers by rehabilitating the water quality and revamping the river banks with the variety of developments. The proposed master plan maximised the social and economic potential of the river by connecting, activating, regenerating and enlivening the people in Kuala Lumpur through the waterfront. Fig. 2 shows the location of Precint7, which is the historical, literal and figurative heart of downtown Kuala Lumpur. Surrounded by impressive historical buildings, the area has all the ingredients of an iconic city, where local and global contingents come to shop, stay and enjoy. The close tie to the birth and history of Kuala Lumpur, Precinct 7 earns the name of Heritage Quarter.

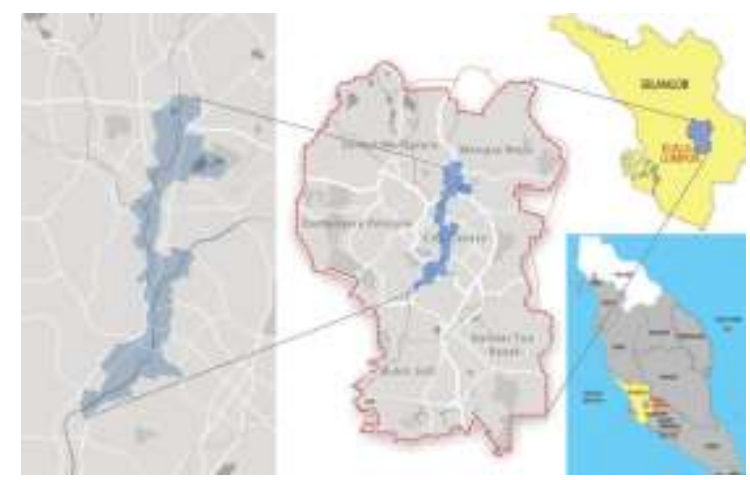

Figure 2: Site Location of ROL Project

Source: http://app.kwpkb.gov.my/greaterk/kv/entrypoint-project-river/ (2014)

The Heritage Quarter demands careful attention to protecting its heritage value not only in the context of existing historic buildings on the site but also the river that runs through the site. 


\subsection{Data Analysis}

Study through direct observation was made. The area of observation chosen was based on a few focal points whereby views of both the waterfront and the urban river can be obtained without obstructions. The author engaged in walking and photographing to assimilate the role of a visitor to experience the urban river (Robson, 2002), as well as evaluating its heritage value. Based on the summary of the previous literature and precedent studies, the elements to preserve the river and enhancing its heritage value are:

- Diversity usage of the river

- Activities along the river

\subsubsection{Diversity Usage of the River}

Analysis of the literature review and precedent studies, the different river, has different usage depending on where the location is and the surrounding area land use. Table 2 shows few possible recommendations for future developments at Precinct 7, ROL Project.

Table 2: Recommendation for Future Developments at Precinct 7, ROL Project

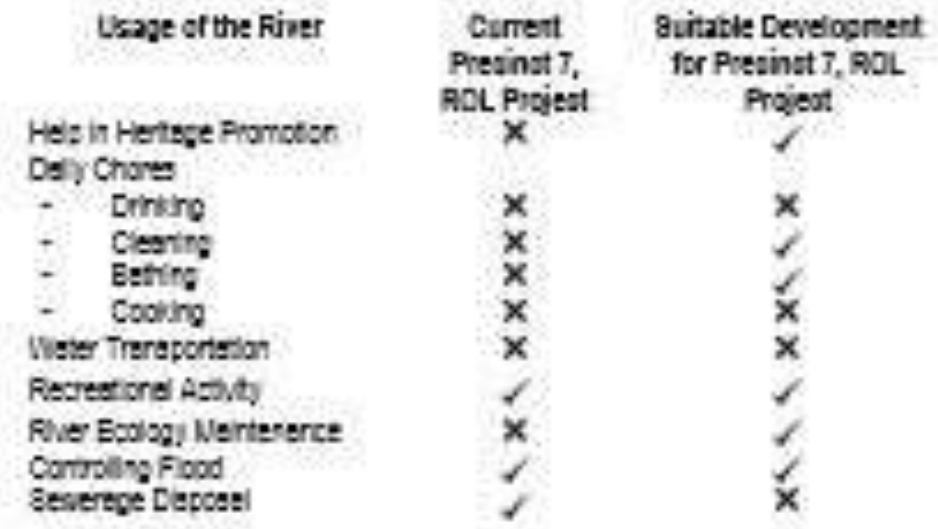

The KL ROL Project in Precinct 7 is located near many heritage buildings and sites (see Figure 3). It is strongly recommended to use these buildings and sites in the future development. These historic buildings and the river that run through them have their respective values. If these values are considered in the master planning, it surely will give more impact in promoting this site.

As one of the aims of the ROL Project is to clean and purify the river, therefore, it is possible to do daily chores mainly washing and bathing in the future. However, for human consumption such as drinking and cooking, it is not recommended. The river in Precinct 7 through proper care and management will serve as touristic purposes and flood mitigation. 


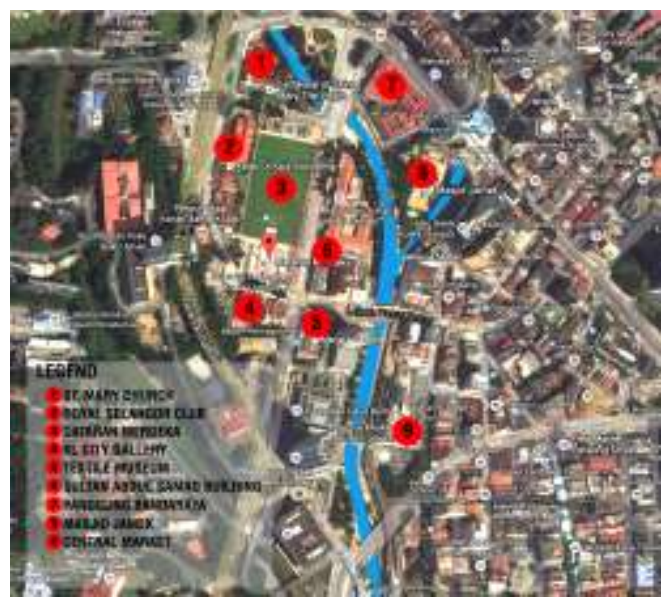

Figure 3: Heritage Building nearby the Precinct 7, ROL Project.
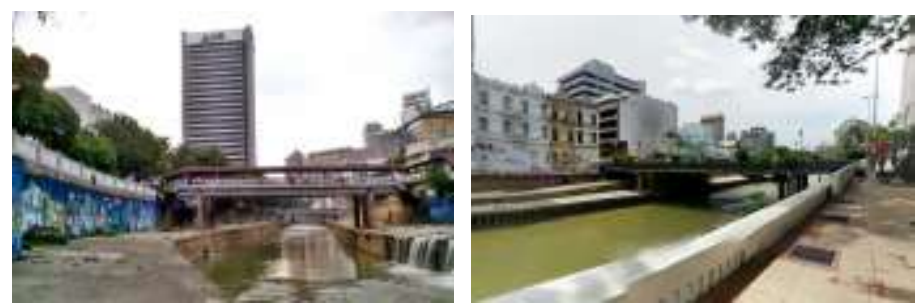

Figure 4: Bridge Conditions at Precinct 7, ROL Project Sources: Google Street View (2014)

Gombak and Klang Rivers along this precinct 7 are not suitable for water transportation mode because of the dimension and size of the river that is too small. Even if the river is being widened in the future, the bridges crossing the river are too low for boats to pass through (see Figure 4). Adapting the Cheonggyecheong River strategy, instead of boat riding along the river for touring and sight seeing the heritage buildings, people need to experience the site by walking along the river. And by doing this, they do not only appreciate the nearby heritage buildings, but they shall also value the river by the experience and touch of the river.

A proper pedestrian and bicycle track need to be installed along the Precinct 7 River since these activities have a demand to some people (Figure 5). Recreational activities can be organised along the stretch of the river since in this existing urban area; healthy activity is very limited. There will be jogging tracks for people to jog along the river that will continue to the nearby lake garden. This activity can be extended to bigger events such as the marathon events that are usually held all the way to Dataran Merdeka. 


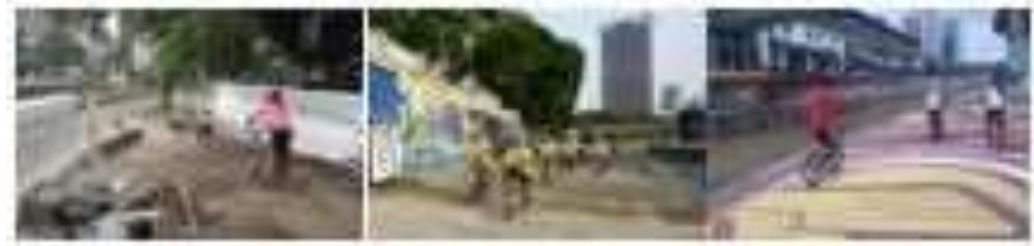

Figure 5: Bicycle Convoy along the Precinct 7, ROL Project Sources: http://ahpekbiker.blogspot.com/2013/04

There is only one section of the river at Precinct 7 that maintains its ecological system (Fig. 6). This site does not only give the opportunity for the river to filter the water naturally but also to implement sustainable water management system to improve on-site storm water quality. We should utilize our tropical climate as this climate environment supports a great diversity of flora and enable the rapid establishment of biodiversity. By restoring natural river features, functions, and in-stream habitat, the river shall reconnect back nature with the people. A place like this shall create a vibrant, bio-diverse environment and focus on specific habitat for amphibians, fish, insect or birds. Native species and naturalized planting should dominate this area and throughout the stretch of the river.

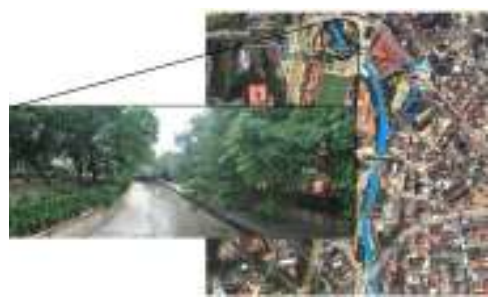

Figure 6: St. Mary's Church Ecological River

Klang and Gombak Rivers' primary function in this present day work as flooded controlling. Malaysia's climate is known for its rain. It makes the flood control a vital in its drainage system management. These flood monitoring rivers still need to be functional to its purpose. However, a proper system needs to be implanted so that the river does not block by rubbish. With the beautification strategy towards enhancing the river, this approach hopes to change the mentality of people not to throw trash into the river and to make the river as a huge sewerage disposal area.

To diversify the usage of the river, another recommendation was to make use the river as a ritual in religious. As shown in Fig. 7, it was shown that the Masjid Jamek is enhancing the river as it becomes the frontage of the mosque. However, a church was totally back fronting the river. Holy place such as Masjid Jamek, which caters to the Muslims and St. Mary Church, is to the Christians, can make use the river for their religious purpose. In Muslim, it is a must to clean one's body that is called ablution before approaching prayer. Thus, by planning steps at the river convergent of Masjid Jamek, this will direct people to touch the 
water, and thus, ablution can be made. For Christian, on the other hand, the river can be used to collect water for baptism and making holy water.

\section{Activities along the River}

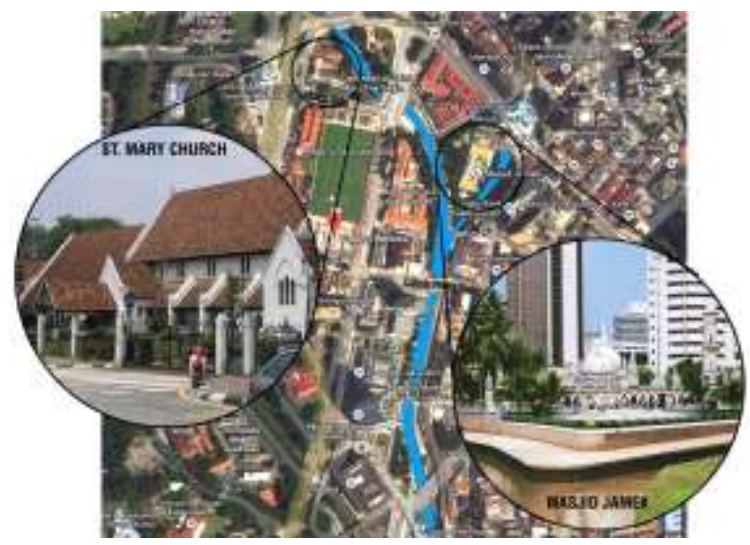

Figure 7: St Mary's Church and Masjid Jamek

Summarize from the precedent studies, the activities along the river is closely related to its usage diversity. From the analysis, it was found that there is a need to activate people to go to the river. It will make them appreciate and value its heritage. The master plan for each river is to connect and link it with the heritage building thus creating a vibrant continuation of activities along the river. To execute the ROL Project at Precinct 7, this master plan technique was proposed and implanted. The potential of dynamic space and static areas was mapped along the Precinct 7 River (Figure 8).

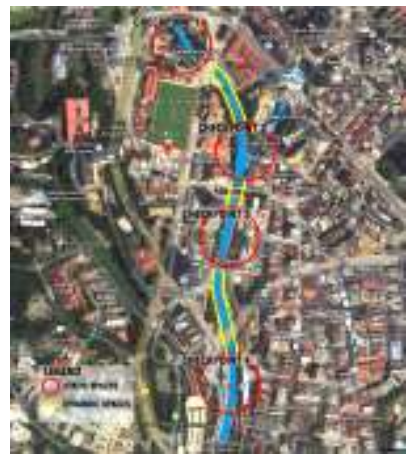

Figure 8: Mapping of the Potential Dynamic and Static Spaces

The pedestrian pathway should be designed in such a way to make people want to continue walking along the river. The walk must have static spaces, also called checkpoints or spots 
for people to rest in between or after a long walk. At this place, various activity infrastructures can be incorporated. Each place should be developed according to its character and potential. In this precinct, four checkpoints were identified. Each checkpoint has its potential. It can be further designed to strengthen its identity by providing facilities and infrastructures. These will increase the community participation and ultimately improve the environment quality.

Through the dynamic and static spaces, that comprises a 'system of places connected by routes', the continuity of activities in the urban area shall make it more pleasing and pleasurable. The dynamic areas provide the sense of 'movement and change' and the static areas imply the meaning of 'rest and completeness'. The mixed experience created by the journey through the dynamic and static spaces can be more valuable once it is interconnected with preserved heritage buildings. Preserving heritage buildings retains the cultural memory of the cityscape. That will educate the people about its cultural landscape and buildings amid the surrounding modern development. It will also maintain the visual interest of its communities, passers-by and defines the character of the city.

The dense and historically sensitive nature of the Heritage Quarter shall only allow controlled redevelopment and urban infill as the primary method of revitalization. The main aims are to increase the activities within the area and increase people traffic flow with better accessibility to all places potentially regarded tourist attractions. The juxtaposition of everyday life and the history, striking adjacency shall be created between an event that is experienced in the present and event that was built in the past (Figure 9). It is possible for the River and heritage area to become extensively linked up through open space and streetscape using existing spaces.

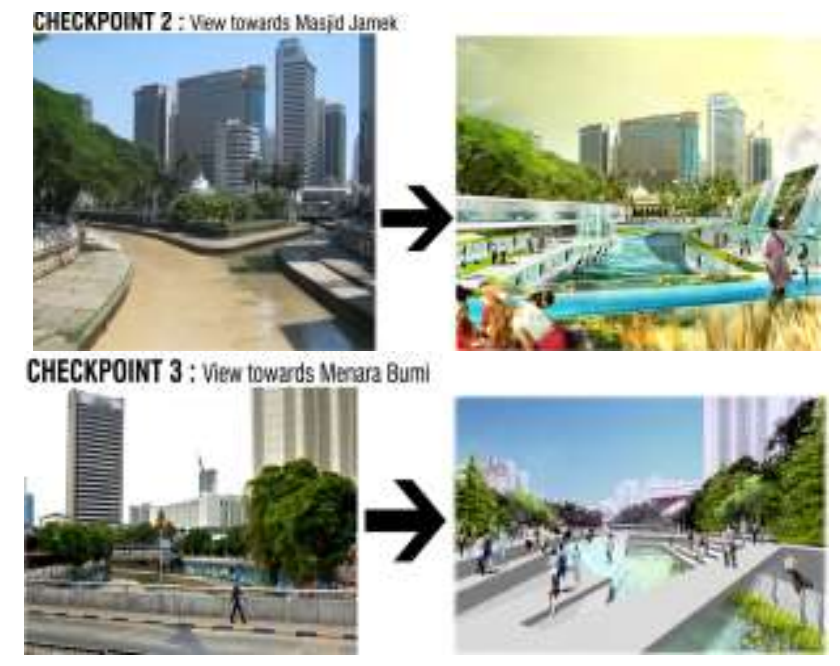




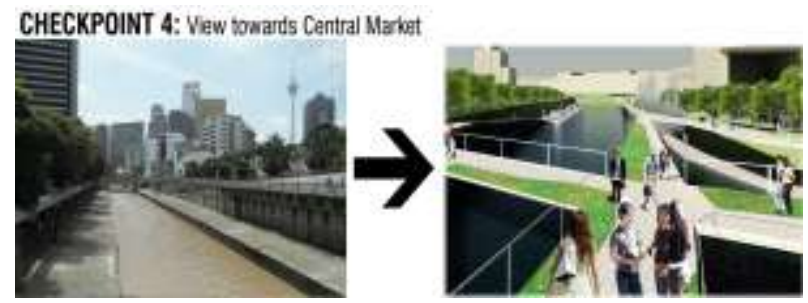

Figure 9: Illustration of Checkpoints Revitalization Possibility

\subsection{Conclusion}

Two ways are identified to design an urban river towards future development while preserving its heritage value. First is to diversify the usage of the river. It can be accomplished through the incorporation of water transportation system, recreational activity, ecological maintenance and flood control mitigation as the various means of river usage. Secondly, activities along the river should be created. Static spaces and dynamic spaces define the activities along the river.

Through the study of Precinct 7, ROL Project, elements of heritage value - the historic buildings along the river and the river itself should be maintained and integrated to preserve heritage value. It is strongly recommended that for the future, proper development could complement this heritage value in a creative way, bringing in today's generation and the future's generation to appreciate the past.

A river is not a static object. Cleaning the river at only one section will never work because the river flows from the upstream right up to the end where it meets the sea channel. Thus, to keep on maintaining and appreciating the river value, the cleaning of the whole stretch of the river that runs through the Kuala Lumpur from the emergence of the upstream of Precinct 1 until Precinct 9, should be further researched. Awareness and educational programmes to care and appreciate the river should be consistently and efficiently implemented. This study should be developed throughout the whole Kuala Lumpur to save and value the river.

\section{Acknowledgement}

The authors would like to thank Universiti Teknologi MARA and the Faculty of Architecture, Planning and Surveying for the infrastructural and technical support.

\section{References}

Abdul Majid, N.H. (2014). River of Life Development at Dataran Merdeka, Kuala Lumpur. Unpublish Design Thesis.UiTM.

Carmona, M., et al. (2003). Public Places Urban Spaces. The Dimensions of Urban Design. Oxford: Architectural Press. Page 312. 
De la Torre, M. \& Mason, R. (2002). Assessing the Values of Cultural Heritage. Research Report. The Getty Conservation Institute. Los Angeles.

Google Street View (2014). Retrieved on 30 September 2014.

http://app.kwpkb.gov.my/greaterklkv/entrypoint-project-river/ (2014). Retrieved on 3 October 2014.

http://ahpekbiker.blogspot.com/2013/04. Retrieved on 3 October 2014.

LeBlanc, F. (1993). Is everything heritage? ICOMOS Canada Bulletin, 2(2), 2e3.

Lynch, K. (1960). The Image of the River. Massachussetts, MIT Press, Cambridge.

Robson, C. (2002). Real World Research: A Resource for Social Scientists and Practitioner-Researchers, 2nd ed. Oxford: Blackwell.

UNESCO, (2007). World Heritage Centre. Retrieve from http:whc.unec.org/en/ about/. Retrieved on 23 November 2014.

Widodo, J. (2012) Urban Environment and Human Behaviour: Learning from History and Local Wisdom; Social and Behaviour Sciences, Volume 42, Issue 4, 30 September 2012, Pages 6-11 